\title{
Monomeric pituitary growth hormone and prolactin variants in man characterized by immunoperoxidase electrophoresis
}

\author{
Sylvain Meuris, Michal Svoboda*, Maria Vilamala, Jean Christophe* and Claude Robyn \\ Human Reproduction Research Unit, Université Libre de Bruxelles at the Hôpital Saint-Pierre, 322 Rue Haute, \\ B-1000 Brussels and ${ }^{*}$ Department of Biochemistry and Nutrition, Medical School, Université Libre de Bruxelles, \\ 115 Boulevard de Waterloo, B-1000 Brussels, Belgium
}

\section{Received 17 February 1983}

\begin{abstract}
Immunoperoxidase electrophoresis, combining SDS-ME-PAGE and the 'double bridge' immunoperoxidase staining was applied to crude human pituitary homogenates. With anti-hGH and antihPL sera, 4 hGH-related monomers were characterized: a $M_{\mathrm{t}} 22000$ peptide corresponding to hGH; a $M_{\mathrm{t}}$ 20000 peptide corresponding to the known hGH variant and two unknown $\mathrm{hGH}$ variants $\left(M_{\mathrm{r}} 65000\right.$ and $\left.M_{\mathrm{r}} 75000\right)$. With anti-ovine, rat and human PRL sera, 4 PRL-related monomers were immunostained: one comigrated with purified hPRL $\left(M_{\mathrm{r}} 25000\right)$, and 3 were unknown $\left(M_{\mathrm{r}} 29000 ; M_{\mathrm{r}} 45000 ; M_{\mathrm{t}} 16000\right)$.
\end{abstract}

\section{Growth hormone Prolactin Human pituitary Pleomorphism Immunochemistry} Electrophoresis

\section{INTRODUCTION}

Immunocytochemistry (ICC) is such a sensitive immunological method that the use of the doublebridge immunoperoxidase technique [1] is considered to allow the detection of $<1 \mathrm{pg}$ of a given protein/cell. Thus, ICC procedures are widely used to screen the cellular localization of numerous peptidic hormones. Unfortunately, specific ICC staining with an anti-hormone serum demonstrates neither the homogeneity of the protein detected nor its identity with the purified protein used as immunogen. Methodological artefacts or crossreactions of specific antisera with unrelated peptides are of further concern when unanticipated ICC staining is observed in a given tissue [2].

Abbreviations: GH, growth hormone; h, human; hPL, human placental lactogen; ICC, immunocytochemistry; IPE, immunoperoxidase electrophoresis; ME, 2-mercapthoethanol; NRS, normal rabbit serum; NSS, normal sheep serum; NTC, nitrocellulose; PAGE, polyacrylamide gel electrophoresis; PRL, prolactin; sArGG, sheep anti-rabbit gamma globulin; SDS, sodium dodecyl sulfate
To obviate such pitfalls and to make full use of the sensitivity of ICC in the physico-chemical characterization of immunoreactive peptidic hormone variants, we developed a new analytical technique combining the high separating power of SDS-polyacrylamide gel electrophoresis in the presence of ME [3] and the extreme sensitivity of the double-bridge immunoperoxidase staining [1]. This technique, we call 'immunoperoxidaseelectrophoresis' (IPE), can be directly applied to whole tissue homogenates. Here, IPE was applied to the human pituitary to separate and characterize the molecular forms of hGH and hPRL. This gland is known to contain mg amounts of hGH and only $\mu \mathrm{g}$ amounts of hRPL [4]. In [5], $15 \%$ of the hGH content of the pituitary was shown to consist of a lower- $M_{\mathrm{r}}$ variant, characterized by a 15 amino acid deletion (between positions 32 and 46). No such heterogeneity of monomeric forms has been reported so far for hPRL.

\section{MATERIALS AND METHODS}

Three normal human pituitaries from elderly pa- 
tients $(1 \&, 2 \sigma)$ were removed at autopsy in $<6 \mathrm{~h}$ after death. The posterior lobe was discarded and the anterior lobe stored in liquid nitrogen until use.

Thawed tissue $(50 \mathrm{mg})$ were homogenized in $1 \mathrm{ml}$ SDS-ME buffer [125 mM Tris- $\mathrm{HCl}$ ( $\mathrm{pH} \mathrm{6.8)} \mathrm{con-}$ taining $1 \%$ SDS, $1 \%$ ME, $20 \%$ sucrose, and $0.01 \%$ phenol red as tracking dye]. The homogenate was sonicated at $120 \mathrm{~W}$ for $1 \mathrm{~min}$, boiled for $1 \mathrm{~min}$, and centrifuged at $50000 \times \mathrm{g}$ for $20 \mathrm{~min}$. The supernatant was adequately diluted in SDS-ME buffer and $10 \mu \mathrm{l}$ aliquots were applied to the top of a $80 \times 80 \times 0.7 \mathrm{~mm}$ polyacrylamide gel as in [3], with $5 \%$ acrylamide for the stacking gel and $14 \%$ acrylamide for the separating gel. SDS-PAGE in the GE $2 / 4$ apparatus from Pharmacia (Uppsala) was run at $60 \mathrm{~V}$ during sample migration in the stacking gel, then continued at 120 $\mathrm{V}$ until the tracking dye had reached the bottom of the gel. Purified hPRL (NIAMDD I-6, AFP-2284C2, NIH) diluted at $5 \mu \mathrm{g} / \mathrm{ml}$ SDS-ME buffer, and boiled for $1 \mathrm{~min}$ before SDS-PAGE served as a reference.

The electrophoretic transfer of proteins from the gel to nitrocellulose (NTC) was achieved by inserting the gel between two sheets of NTC paper (Sartorius $\mathrm{GmbH}$, Göttingen) as in [6] and applying a transverse electrical field of $30 \mathrm{~V}$ for $120 \mathrm{~min}$. The electrode buffer was made of $25 \mathrm{mM}$ Tris, $192 \mathrm{mM}$ glycine, and $20 \%(\mathrm{v} / \mathrm{v})$ methanol $(\mathrm{pH} 8.3)$. Under these conditions, a standard of ${ }^{125}$ I-hPRL was transferred from the gel onto the cathodic NTC sheet with a yield $>70 \%$. The proteins were fixed in $5 \%$ sulfosalicylic acid, $10 \%$ trichloroacetic acid for $\mathbf{3 0} \mathrm{min}$ and the cathodic NTC sheet was then washed in water. Untransferred proteins remaining on the gel were stained by silver [7].

Washed cathodic NTC sheets were handled by a modified double-bridge immunoperoxidase technique used as for immunocytochemistry $[1,8]$. After immersion for $10 \mathrm{~min}$ in $2 \%(\mathrm{v} / \mathrm{v})$ normal sheep serum (NSS), NTC sheets were incubated for $48 \mathrm{~h}$ at $4^{\circ} \mathrm{C}$ in the presence of one of the following specific rabbit anti-hormone sera: anti-hPRL (AFP-1, NIH), anti-oPRL (Ba-603) [9], anti-oPRL (Ni-770) [10], anti-rPRL (Re-3) [11], anti-hGH (Ra-2) [12], and anti-hPL (Du-2) [13]. Each serum was diluted $1: 1000$ or more in PBS-NSS buffer made of $10 \mathrm{mM}$ sodium phosphate ( $\mathrm{pH} 7.4)$ containing $145 \mathrm{mM} \mathrm{NaCl}, 1 \%(\mathrm{v} / \mathrm{v})$ normal sheep serum, and $0.1 \% \mathrm{NaN} 3$. As controls [14], NTC sheets were incubated with PBS-NSS buffer alone or with non-immune rabbit serum (NRS) diluted as the antisera. The anti-hormone antibodies, attached to the immunoreactive sites in NTC sheets were then exposed for $10 \mathrm{~min}$ to sheep anti-rabbit IgG serum (sA-rGG) [9] diluted 1:100 in PBS-NSS. The remaining free valences of this antiserum were next allowed to bind for $10 \mathrm{~min}$ to the $\mathrm{Fc}$ portion of horseradish peroxidase-rabbit antiperoxidase IgG complexes (PAP Dako Immunoglobulins, Denmark) diluted 1:100 in PBS-NSS. This two-

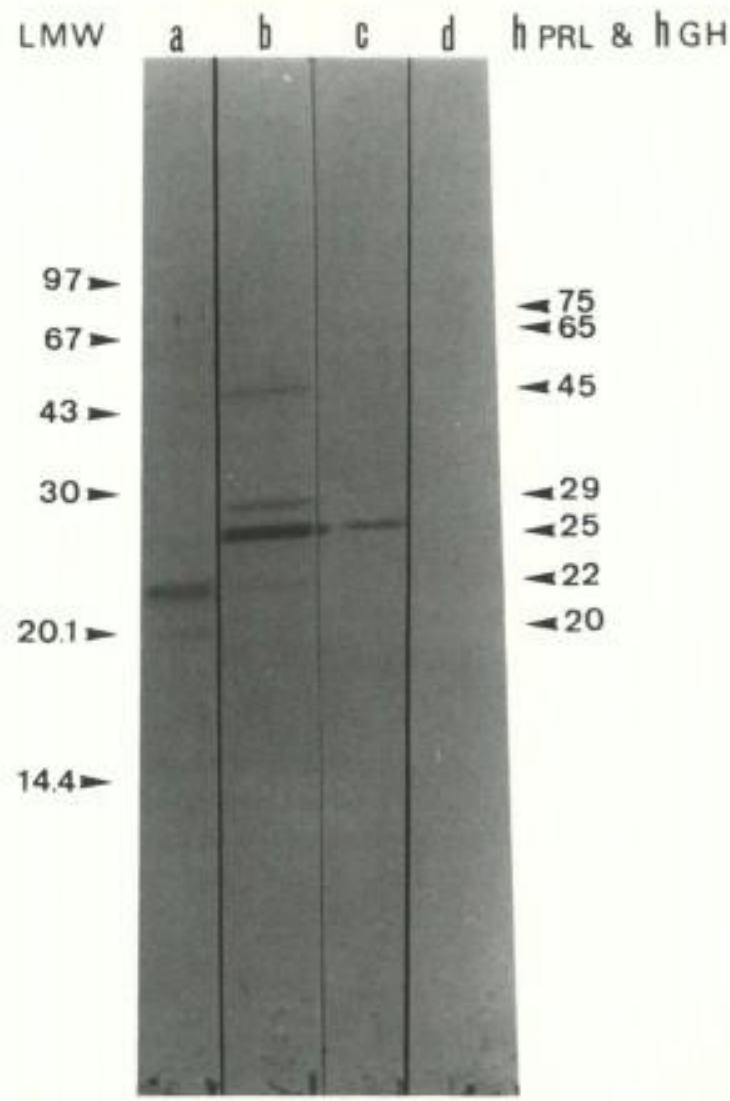

Fig. 1. IPE pattern of a crude human pituitary homogenate (lanes a,b; $50 \mu \mathrm{g}$ tissue wet wt in $10 \mu \mathrm{l}$ SDS-ME buffer) and of purified human prolactin (lanes c,d; $50 \mathrm{ng}$ in $10 \mu \mathrm{l}$ SDS-ME buffer) with anti-hGH (lanes a,d) and anti-oPRL (lanes b,c) sera. The two antisera were diluted 1:10000. The mobilities and corresponding $M_{\mathrm{r}}\left(\times 10^{-3}\right)$ of proteins of the low- $M$ (LMW) SDS calibration kit are indicated by the arrow: on the left. The $M_{\mathrm{r}}\left(\times 10^{-3}\right)$ corresponding to the protein bands immunostained with anti-hGH and antioPRL sera are indicated on the right. 
step procedure with $\mathbf{s A - r G G}$ and PAP was repeated once, to increase the number of peroxidase molecules/immunoreactive site [1]. Peroxidase was then revealed with $3,3^{\prime}$-tetrahydrochlorodiaminobenzidine $(0.5 \mathrm{mg} / \mathrm{ml}, 50 \mathrm{mM}$ Tris $-\mathrm{HCl}$, $\mathrm{pH}$ 7.6), activated with $0.2 \%(\mathrm{v} / \mathrm{v}) \mathrm{H}_{2} \mathrm{O}_{2}$ for 10 min, giving a brown-coloured reaction product. The immunostained NTC sheet was dried and the app. $M_{\mathrm{r}}$ of immunostained bands was measured with reference to a low- $M_{\mathrm{r}}$ markers SDS calibration kit of Pharmacia consisting of phosphorylase $b\left(M_{\mathrm{r}} 94000\right)$, bovine serum albumin $\left(M_{\mathrm{r}} 67000\right)$, ovalbumin $\left(M_{\mathrm{r}} 45000\right)$, carbonic anhydrase $\left(M_{\mathrm{r}}\right.$ $30000)$, trypsin inhibitor $\left(M_{t} 20100\right)$, and $\alpha$ lactalbumin $\left(M_{\mathrm{T}}\right.$ 14400). In several IPE experiments, cytochrome $c\left(M_{\mathrm{r}} 12700\right)$ was included as internal coloured standard at $0.3 \mathrm{mg} / \mathrm{ml}$. The double-bridge immunoperoxidase technique gave a distinct brown-coloured spot, when as little as 1.0 pg standard PRL was applied directly on NTC paper in $1.0 \mu \mathrm{l}$ PBS (not shown).

\section{RESULTS}

By IPE of crude homogenates of human pituitary, anti-hGH and anti-hPL sera allowed the immunostaining of the same 4 protein bands: a predominant $M_{\mathrm{r}} 22000$ form, a band with $M_{\mathrm{r}}$ 20000 , and 2 fainter bands with $M_{\mathrm{r}} 65000$ and 75000 (fig. $1 \mathrm{a}, 2 \mathrm{k}, 1$ ).

The staining pattern obtained for hPRL by IPE of the same tissue homogenates was also complex. The 2 anti-oPRL sera and the anti-rPRL serum always revealed the same $4 M_{\mathrm{r}} 25000, M_{\mathrm{r}} 29000$, $M_{\mathrm{r}} 45000$ and $M_{\mathrm{r}} 16000$ peptides in the order of decreasing immunostaining (fig. $1 \mathrm{~b}, 2 \mathrm{a}-\mathrm{h}, 3$ ). A purified hPRL preparation tested by IPE with the same 3 anti-PRL sera showed a single $M_{\mathrm{r}} 25000$ peptide (fig. 1c) corresponding to the $M_{\mathrm{r}} 25000$ band stained by silver on polyacrylamide gel.

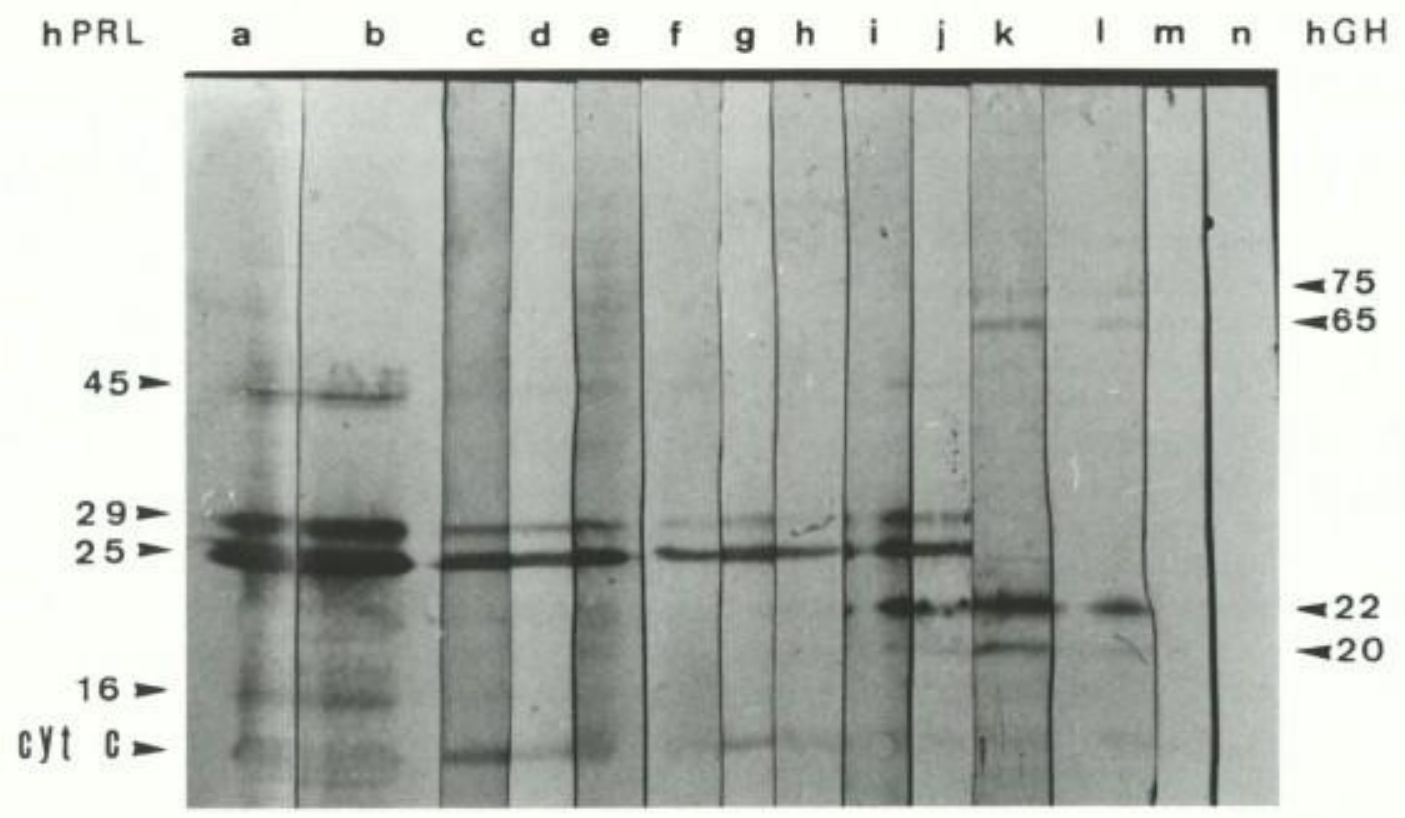

Fig. 2. IPE pattern of a human pituitary homogenate corresponding to $250 \mu \mathrm{g}$ tissue wet wt (lanes a, b) and $25 \mu \mathrm{g}$ tissue wet wt (lanes $c-n$ ). The nitrocellulose strips were incubated with 5 antisera: anti-rPRL (lanes a,c,d), anti-oPRL (Ba-603) lanes b,e,f), anti-oPRL (Mi-770) (lanes g,h), anti-hPRL (lanes i,j), anti-hPL (lanes k,l). Control strips were incubated with normal rabbit serum (lane m), and with PSB-NSS (lane n). The sera were diluted 1:1000 in lanes a,b,c,e,g,i,k,m, and $1: 10,000$ in lanes, $d, f, h, g, 1$. The mobilities and corresponding $M_{\mathrm{r}}\left(\times 10^{-3}\right)$ of the immunoreactive forms of hPRL and hGH are shown, respectively, on the left and right sides of the figure by reference to a log- $M_{\mathrm{t}}$ standard curve obtained with the calibration kit (see fig. 2). In addition, cytochrome $c$ (cyt $c, M_{r} 12700$ ) was added to the initial homogenate as an internal coloured standard. 


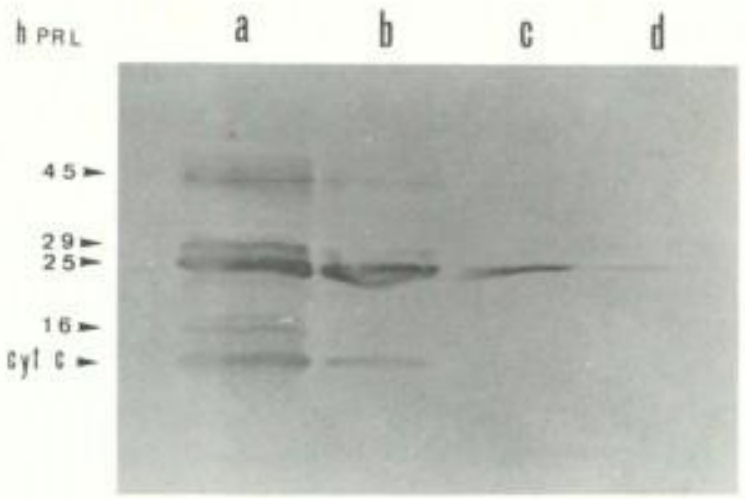

Fig. 3. Semi-quantitative IPE analysis of hPRL variants in a human pituitary homogenate, using anti-oPRL (Ba 603 ) serum at a 1:10000 dilution. Decreasing tissue wet weight in $10 \mu \mathrm{l}$ aliquots were applied per lane of the gel: $250 \mu \mathrm{g}$ (lane a); $25 \mu \mathrm{g}$ (lane b), $2.5 \mu \mathrm{g}$ (lance c); and $0.25 \mu \mathrm{g}$ (lane d). $M_{\mathrm{r}}$-Values of the immunoreactive forms of hPRL are indicated on the left side of the figure by the arrows. The presence of cytochrome $c$ (cyt. $c$ ) added as an internal coloured standard, is also apparent.

When incubated with the anti-hGH serum, the hPRL band was not immunostained (fig. 1d).

A semi-quantitative evaluation of the immunoreactivity of these four proteins bands was performed by serial dilutions $(10 \times$ dilution factor) of a whole pituitary homogenate (fig. 3 ). The $M_{r}$ 25000 peptide was apparently the most abundant, the $M_{\mathrm{r}} 29000, M_{\mathrm{r}} 45000$, and $M_{\mathrm{r}} 16000 \mathrm{im}$ munoreactive variants being, respectively, 10-, 100 , and 1000-times less abundant and/or immunoreactive.

The IPE profiles of crude human pituitary homogenate obtained with the anti-hPRL serum used consisted of 6 protein bands: 4 bands corresponded to those stained by the anti-oPRL and anti-rPRL sera, while the additional 2 , revealed at similar antiserum dilution, comigrated with the $M_{r}$ 20000 and $M_{\mathrm{r}} 22000$ peptides stained with the antihGH and anti-hPL sera (fig. 2i,j).

No staining of protein bands was obtained by IPE of crude human pituitary homogenates, when using PBS-NSS or NRS instead of the antihormone sera (fig. $2 \mathrm{~m}, \mathrm{n}$ ).

\section{DISCUSSION}

The anti-hGH and anti-hPL sera stained four protein bands by IPE of crude homogenates of the same pituitary, at the same antibody dilution. Two of them corresponded to well-characterized forms of hGH [4]: the predominant form of hGH $\left(M_{\mathrm{r}}\right.$ $22000)$ and its variant $\left(M_{\mathrm{r}} 20000\right)$. The two other slow migrating immunoreactive forms $\left(M_{\mathrm{r}} 65000\right.$ and 75000 ) stained by IPE at the same antibody dilution are likely to be hGH-related. These two slow forms were, like the two main forms, stained with the anti-hPL serum as well as with the antihGH serum. Since there is some $80 \%$ homology between the amino acid sequences of $\mathrm{hGH}$ and hPL [15], this observation confirms that the two slow migrating bands were antigenically related to hGH. It is, indeed, unlikely that the IPE staining of these slow migrating forms, obtained with antihGH and anti-hPL sera, was due to non-specific antibodies raised against identical protein contaminants common to pituitary and placenta. Finally, since proteins in human pituitaries were separated by SDS-PAGE under reducing conditions, the $M_{\mathrm{r}} 65000$, and 75000 forms were not hGH disulfide-linked oligomers, but represented hGH-related monomeric variants.

Concerning PRL, the four anti-PRL sera used were able to stain the same 4 protein bands in human pituitary homogenates. The predominant one $\left(M_{\mathrm{r}} 25000\right)$ corresponds to purified prolactin. Since the three other forms $\left(M_{\mathrm{r}} 29000,45000\right.$ and 16000 ) were immunostained with antisera raised against pituitary PRL purified from 3 animal species, we consider them as immunoreactive variants of PRL. So far, these monomeric PRLrelated peptides were not described. Such heterogeneity of PRL should not be confused with that revealed by exclusion chromatography. By this procedure, unreduced pituitary PRL is found in high $M_{\mathrm{r}}$ fractions [16]. These forms are not monomeric variants.

Here, the $M_{\mathrm{r}} 29000$ and $M_{\mathrm{r}} 45000 \mathrm{PRL}$ forms were seen despite the reducing conditions and were, thus, monomeric forms.

Despite the $26 \%$ homology between the amino sequences of hGH and hPRL $[17,18]$, no distinct immunological cross-reaction could be detected by IPE except with the anti-hPRL serum. The lack of specificity should be conceivably due to a contamination of the immunogen with hGH variants and/or to antibodies recognizing antigenic determinants common to hPRL and hGH variants. 
Here IPE allowed the demonstration of the $M_{\mathrm{r}}$ heterogeneity of growth hormone and prolactin in crude homogenate of the human pituitary without previous purification. We demonstrated a similar heterogeneity of these hormones (including low $M_{\mathrm{r}}$ variants) in the rat pituitary removed immediately after decapitation (unpublished).

It would be of great interest to know which of these forms are secreted and whether they are biologically active and of physiopathological significance.

IPE proved to be a simple, highly sensitive antibody-saving technique, susceptible of extensive application in biomedical research.

\section{ACKNOWLEDGEMENTS}

We thank Dr J. Flament-Durand for providing the human pituitaries and Mrs H. Preszow and J. Ballinckx for their help in preparing the manuscript. This work was supported by grants 3.4501.81 and 3.4504.81 from the Fund for Medical Scientific Research (Belgium) and a grant from the City of Brussels. Sylvain Meuris is Senior Research Assistant from the National Fund for Scientific Research (Belgium).

\section{REFERENCES}

[1] Ordonneau, P., Lindström, P.B.M. and Petrusz, P.J. (1981) J. Histochem. Cytochem. 29, $1397-1404$.

[2] Yallow, R.S. and Eng, J. (1981) Peptides 2 (suppl. 2), 17-23.
[3] Laemmli, U.K. (1970) Nature 227, 680-685.

[4] Lewis, U.J., Singh, R.N.P., Tutwiler, G.F., Sigel, M.B., Vanderlaan, E.F. and Vanderlaan, W.P. (1980) Rec. Prog. Hormone Res. 36, 477-508.

[5] Lewis, U.J., Bonewald, L.F. and Lewis, L.J. (1980) Biochem. Biophys. Res. Commun. 92, $511-516$.

[6] Towbin, H., Staehelin, T. and Gordon, J. (1979) Proc. Natl. Acad. Sci. USA 76, 4350-4354.

[7] Morrissey, J.H. (1981) Anal. Biochem. 117, 307-310.

[8] Meuris, S., Verloes, A. and Robyn, C. (1983) submitted.

[9] Meuris, S., Soumenkoff, G., Malengrau, A. and Robyn, C. (1980) J. Histochem. Cytochem. 28, $1347-1350$.

[10] Davis, S.L., Reichert, L.E. jr and Niswender, G.D. (1971) Biol. Reprod. 4, 145-153.

[11] Seo, H., Refetoff, S., Scherberg, N., Brocas, H. and Vassart, G. (1979) Endocrinology 105, 1481-1487.

[12] Martin-Comin, J. and Robyn, C. (1976) J. Histochem. Cytochem. 24, 1012-1016.

[13] Dujardin, M., Robyn, C. and Wilkin, P. (1977) Biol. Cell. 30, 151-154.

[14] Petruz, P., Ordonneau, P. and Finley, J.C.W. (1980) Histochem. J. 12, 333-348.

[15] Niall, H.D., Hogan, M.L., Tregear, G.W., Segre, G.V., Hwang, P. and Friesen, H. (1973) Rec. Progr. Horm. Res. 29, 387-416.

[16] Lewis, U.J. and Singh, R.N.P. (1973) in: Human Prolactin (Pasteels, J.L. and Robyn, C. eds). Elsevier/Excerpta Medica, Amsterdam, New York.

[17] Cooke, N.E., Coit, D., Shine, J., Baxter, J.D. and Martial, J.A. (1981) J. Biol. Chem. 256, 4007-4016.

[18] Shome, B. and Parlow, A.F. (1977) J. Clin. Endocr. Metab. 45, 1112-1115. 